\title{
A Learning Organization as a Mediator of Leadership Style and Firms' Financial Performance
}

\author{
Nont Sahaya ${ }^{1}$ \\ ${ }^{1}$ Graduate School of Commerce, Burapha University, Chonburi, Thailand \\ Correspondence: Nont Sahaya, Graduate School of Commerce, Burapha University, Chonburi, Thailand. Tel: \\ 662-38-394-900. E-mail: sahayanont@yahoo.com
}

\author{
Received: April 15, 2012 Accepted: May 30, 2012 Online Published: July 16, 2012 \\ doi:10.5539/ijbm.v7n14p96 URL: http://dx.doi.org/10.5539/ijbm.v7n14p96
}

\begin{abstract}
The purpose of this study is to examine and identify the influence of learning organization as a mediator on the relations between leadership styles (transformational, transactional and passive-avoidant) and ROA. Multifactor Leadership Questionnaire (MLQ 5x-short) for leadership styles while Dimensions of the Learning Organization Questionnaire (DLOQ) for learning organization testing were used in this study with data of 400 respondents from 100 firms in The Stock Exchange of Thailand 100 (SET100). The results of conceptual model by regression analysis were mostly positive: the mediators Promote inquiry, and Provide strategic (elements of learning organization) mediated partially on relationship between IC (transformational) and ROA. Moreover, the mediator Empower people (elements of learning organization) mediated partially on relationship between CR (transactional) and ROA while no (learning organization) mediated on relationship between passive-avoidant leadership style and ROA. The contributions of this study are two aspects. Practical aspect, the significance of IC, $\mathrm{CR}$, and LF leadership styles effect on financial performances. Promote inquiry, Provide strategic, Empower people dimensions of learning organization mediate on relationship between IC, CR leadership styles and ROA. Understanding is upon conceptual model that examine and identify on the leadership styles, learning organization, and ROA financial performance for theoretical aspect.
\end{abstract}

Keywords: learning organization, leadership style, firms' financial performance, mediation effect

\section{Introduction}

Leadership's characteristics are significant effect to firm or organizational performance (Avolio and Bass, 1990; Bycio, Hacket and Allen, 1995), because the leadership's characteristics have an influence over their followers and firm performance. An organization is able to improve itself to be a learning organization has more effective firm performance, more increasing knowledge, more creation and more competitiveness (Garvin, 1993; Marquardt, 2002). Therefore, not only the styles of leader to take competitive advantage but learning organization also enhance knowledge and skills to create good firm performance (DiBella \& Nevis, 1998; Marquardt, 2002; Watkins \& Marsick, 1993).

Researcher prefers to use the full-range of leadership theory of Bass and Avolio (2004) in this study. The Multifactor Leadership Questionnaire (MLQ 5x-short) leader form is utilized as an instrument to measure leadership styles. The Dimensions of the Learning Organization Questionnaire (DLOQ) constructed by Watkins \& Marsick $(1993,1997,2003)$ is also provided to use examine seven dimensions of learning organization. ROA is a return on assets ratio which is used for determine performance of the firm with compare to other. The mediation effect methodology by Baron and Kenny (1986), and Kenny et al. (1998) is used to examine mediation effect by multiple regressions analysis. Samples of this study are 400 respondents from 100 companies listed in the Stock Exchange of Thailand 100.

The leadership styles are able to effect on organizational performance. If those firms are learning organization, the influences of learning organization are able to impact toward efficiency of leadership styles and organizational performance or not and how. The purpose of this study is to examine and identify the influence of learning organization mediator on relationship between leadership styles (transformational, transactional and passive-avoidant) and ROA. 


\section{Literature Review}

\subsection{The Full-Range of Leadership Theory (Nine Factors Model of Leadership Styles)}

Burns (1978) initialed a notion of transformational leadership. He distinguished between characteristics of transformational and transactional leadership. Bass (1985) was an original conception with the six-factor model of leadership styles. In 1990 Bass and Avolio proposed that a nine factor model were the characteristics of transformational and transactional leadership. Avolio \& Bass (1991) suggested "Full Range Leadership Theory" (FRLT). The constructs of this theory was consist of three types of leadership behavior: transformational, transactional, and no transactional laissez-faire leadership, which were represented by nine different factors. However, Avolio et al. (1991) revised the Bass's (1985) theory to concepts of "Four Is" of transformational leadership. Later, Bass and Avolio (1993) modified "The Four Is" to seven leadership factors. Bass and Avolio (1994) again modified anew the active and passive forms of seven leadership factors to eight factors of leadership. Moreover, Bass and Avolio (1995) added the category of Laissez-faire to another style and separated the idealized influence factor into attributed idealized influence factor and behavior idealized influence factor. After 1995, Several researchers (Bass and Avolio, 1996, 1997; Bass, 1997; Den Hartog et al., 1997; Avolio et al.,1999; Bass et al., 1999; Goodwin, Wofford, \& Whittington, 2001; Antonakis, et al.,2003; Bass, Avolio, Jung, \& Berson,2003; Avolio \& Bass, 2004; Barbuto Jr., 2005; Rowold \& Heinitz, 2007) have still used the nine factors version to based on the several researches while some researchers had recommended additions or deletions the items of factors from nine factors model for their studies (Bass, Avolio, and Jung, 1995; Lowe et al.,1996; Avolio and Bass, 1997; Bass,1996a, 1998; Avolo, Bass, and Jung, 1999; Dumdum et al., 2002; Judge and Piccolo, 2004).Until, Bass and Avolio (2004) revised the latest version of a nine-factor or full range of leadership model which consists five factors of transformational leadership style as: idealized influence (attributed), idealized influence (behavior), inspirational motivation, intellectual stimulation, and individualized consideration; two factors of transactional leadership styles as: contingent reward and management-by-exception (active); and two factors of passive-avoidant leadership style as: management-by-exception (passive) and laissez-faire leadership style.

\subsection{Transformational Leadership Styles}

Transformational leaders are able to stimulate and motivate the followers to perform beyond expectation of the working's standard (Bass, 1985). Transformational leaders not only exchange between rewards and the leaders' requirement but also motivate the followers to transcend their self-interests for the goals. Moreover, they are able to change members' behaviors to encourage their visions for achievement (Howell \& Avolio, 1993). The followers are going to understand and share their interests to leaders when they trusted and respected for leaders (Bass \& Avolio, 1993). Therefore, leaders derived the influence from followers to transform organization for their vision's development in the future (Avolio and Bass, 1994). The degree of influence from leaders to followers is results of followers' reactions. These reactions will assess and select the styles of leaders which are appropriate or not for them (Densten, Santora, Sarros, Tanewski, \& Winter, 2002). Moreover, transformational leaders are excellent motivators because they emphasize on the people more than results. The behaviors of transformational leadership are consist of employees developing and treating, problem solving, others interesting, creative promotions and adaptive solutions, others respect, others confidence, achievement focusing, common benefit focusing, optimistic focusing, enthusiastic focusing, and self-actualization focusing (Harland et al., 2005). Goodwin, Whittington, and Wofford (2001) suggested that transformational leadership style of the full-range leadership model is the culmination of many leadership theories. Transformational leadership styles in full-range leadership model were comprised of five factors (Bass \& Avolio, 2004). The details are following:

\section{Idealized Influence (Attributed)}

Leaders, who have charismatic character such as support and instill the pride to the followers, go beyond self-interest for the advantage of group and organization, encourage proceed to build trust and respect to leader and exhibit the sense of self-confident and direction (Avolio \& Bass, 2003).

\section{Idealized Influence (Behavior)}

Leaders, who have charismatic actions such as highlight on the sense of purpose and performance, emphasize on the moral and ethics for decisions (Avolio \& Bass, 2003).

\section{Inspirational Motivation}

Leaders, who encourage their followers to view optimistically accomplishment in the future, communicate clearly with their vision and reveal certainly toward the goals that they will be reach (Bass \& Avolio, 2004). 
Intellectual Stimulation refers to leaders who stimulate the sense of logic and analysis of followers to creative the notions for problems solving.

\section{Individualized Consideration}

Leaders, who have behaviors of advising, encouraging, teaching, coaching, and paying attention to the individual talents and needs of follower rather than as a member of the group.

\subsection{Transactional Leadership Style}

Concept of Burns' (1978), he proposed that transactional leadership style concern in transaction of rewards for followers' performance. Later, Bass (1985) defined that transactional leadership is the essentially exchange-oriented base. However, the basic needs of people or exchange are focus on the short-term goals (Waldman, Bass, \& Einstein, 1987; Sergiouvanni, 1990). But the transactional leaders' emotional intelligence is able to increase their effectiveness when they understand how to motivate followers and which rewards are attractive and appropriate to them (Barling, Slater, and Kelloway, 2000). However, transactional leadership styles are comprised of two factors which are contingent rewards and management-by-exception (active) (Bass \& Avolio, 2004). The details of transactional leadership style are following:

\section{Contingent Reward}

Leaders, who have behaviors of expectation clarifying, negotiation, promises making, and contingent rewards offering to followers when the goals are achieved (Bass \& Avolio, 2004).

Management-By-Exception (Active)

Leaders, who have behaviors of active monitor for errors, concentrate on the mistakes and deviations from standard of task, and take immediate actions when the irregularities occurred (Bass \& Avolio, 1994).

\subsection{Passive-Avoidant Leadership Style}

Passive-avoidant leadership styles were comprised of two factors (Bass \& Avolio, 2004). The details are following:

\section{Management-By-Exception (Passive)}

Leaders, who have behaviors of waiting until a problem become serious, wait for things to go wrong before taking action (Avolio \& Bass, 2004). These behaviors were no leadership.

\section{Laissez-Faire Leadership Style}

Leaders, who have behaviors of avoid responsibilities, lake of direction and decisions, loss of influence, fail to communication, and lack of any kind of leadership (Bass, 1985; Geyer \& Steyrer, 1998; Avolio et al., 1999; Antonakis et al., 2003; Avolio \& Bass, 2004; Sarver, 2008).

\subsection{Multi- Factor Leadership Questionnaires (MLQ)}

MLQ instrument was reviewed in several times during two decade since it emerges by Bass (1985). Today, MLQ $5 \mathrm{X}$ version is the new form by Bass and Avolio $(2004,2006)$, contains 45 questions to evaluate the behavior of leadership styles, 36 items to measure nine subcomponents with 5-point of likert scale answering.

\subsection{Learning Organization}

Informal learning was emerged in workplace when employee was trained by the job and learned from the new employee joining at work through coaching, mentoring, co-working, and networking (Dixon, 1997; Marquardt and Alexander, 1999). During 1970 to 1980, training programs concentrated on the educations and knowledge of technologies (Rowden, 2001). In 1990, the themes of training concern about consulting projects for organizational performance (Robinson \& Robinson, 1995). In this year, Senge (1990) established the notions of learning organization in his book, The Fifth Discipline. He proposed that his model on learning organization with five disciplines. In 1991, Peddler et al (1991) explicated that their model is the composition of human resource management function and organization designs that improve firm performance and quality of life in work with eleven elements. Later, Watkins and Marsick (1993) in their book, Sculpting the Learning Organization, They introduced the major of six actions to enhance learning process in organization. Sooner, they revised their model by adding the seventh major of action in process (Marsick \& Watkins, 2003). In 1994, Redding \& Catalanello (1994) explained that their model on learning organization with eleven elements. Later, DiBella \& Nevis (1998) interpreted that their model on learning organization on ten elements. In 2000, Garvin (2000) described that his model on learning organization by five elements. Moreover, Marquardt (2002) explained that his model on learning organization on five subsystems. Each theoretical model of learning organization's concepts as above 
was created from several literature reviews of research and relationship between practice and theory. These notions were several criticized and argued by researchers in other aspects on long period

\subsection{The Seven Dimensions of the Learning Organization}

In 1993, Karan Watkins and Victoria Marsick $(1993 ; 2003)$ suggested that "A learning organization is one that learns continuously and transforms itself......it proactively uses learning in an integrated way to support and catalyze growth for individuals, teams, entire organizations, and the institutions and communities with which they are linked" (p. 8).

Watkins and Marsick (1993) in their book, Sculpting the Learning Organization, They introduced the major of six actions to enhance learning process in organization. Later, they revised their model by adding the seventh major of action in process (Marsick \& Watkins, 2003). The details of seven dimension of learning organization are following:

\section{Creating continuous learning opportunities}

Watkins and Marsick (1993, 1996, 2003) stated that the first dimension refer to continuous learning creation in organization for individual level.

\section{Promoting inquiry and dialogue}

Watkins and Marsick $(1993,1996,2003)$ stated that the second dimension refer to inquiry and dialogue promotion in organization. Moreover, the idea of inquiry is based on open-mined of people to consider problem solutions.

\section{Encouraging collaboration and team learning}

Watkins and Marsick $(1993,1996,2003)$ stated that the third dimension refer to encouraging collaboration and team learning in organization. They repeated the Senge's (1990) interpretation on the significance of team learning which is heightened when team learn the process of framing, reframing, and integrating perspectives.

Establishing systems to capture and share learning

Watkins and Marsick $(1993,1996,2003)$ stated that the fourth dimension refer to establishing systems to capture and share learning. Ability of organizations to learn depends on the congruence of organizational mission and factors which are supported their mission such as strategy, culture, and structure.

Empowering people toward a collective vision

Watkins and Marsick $(1993,1996,2003)$ stated that the fifth dimension refer to empowering people toward a collective vision. Moreover, empowerment is required to use in organization because it can change areas of responsibility, structure, culture, and development in organization.

\section{Connecting the organization to its environment}

Watkins and Marsick (1993, 1996, 2003) stated that the sixth dimension refer to connecting the organization to its environment. They explained that the whole systems of organization must relate to the effect of their internal and external environment.

\section{Strategic leadership to support learning}

Watkins and Marsick $(1993,1996,2003)$ stated that the seventh dimension refer to strategic leadership to support learning. They also suggested the skills for leaders to use in the process of learning in organization which consist of ideas sharing, information for organizational changing, opinions for adaptive changing, reward to encouraging, recognizing to employee development, and proving to new ideas and behaviors.

\subsection{Dimensions of the Learning Organization Questionnaire (DLOQ)}

Watkins and Marsick $(1993,1996,1997)$ constructed the measurement of the learning organization, it is called the Dimensions of the learning organization Questionnaire (DLOQ). Watkins and Marsick (1993, 1996, 1997) provide the DLOQ instrument in order to evaluate the people by individual level and/or group level, and organizational structures by structural/ systems level. The original version of DLOQ comprise of 43 items to measure the seven dimensions of learning organization (Watkins and Marsick, 1993, 1999, 2003). Later, DLOQ is clarified by Yang et al., (2004). Finally, the DLOQ is able to utilize in two forms by 43 items and 21 items to measure the seven dimensions of learning organization (Yang et al., 2004).

\subsection{Firms' Financial Performance}

The financial performance is the gauge to evaluate management's financial ability of the firms (Morgan and 
Strong, 2003). Several researches used the financial rations to measure the financial performance such as return on assets (ROA) (Hitt et al., 1997; Yamin et al., 1999; King and Zeithamel, 2001; Rozeinzweig et al., 2003; Yammessri and Sudhir, 2004; Chajnacki, 2007), return on investment (ROI) (Yamin et al., 1999; Matsuno et al., 2002; Morgan and strong, 2003; Davis, 2005), and etc. The return on assets (ROA) is the most acceptant for evaluating financial performance.

\subsection{The Mediation Effect by Baron and Kenny's Theory}

Baron and Kenny (1986), Judd and Kenny (1981), and Kenny et al., (1998) developed the mediation effect methodology theory from mediation testing in psychological research (Figure 1 Conceptual Mediation Model). This method consists of four steps of variables relationship establishing processes and three equations testing. Moreover, the final confirmation on significance of mediation effect was tested by $\mathrm{Z}$ score.

A.

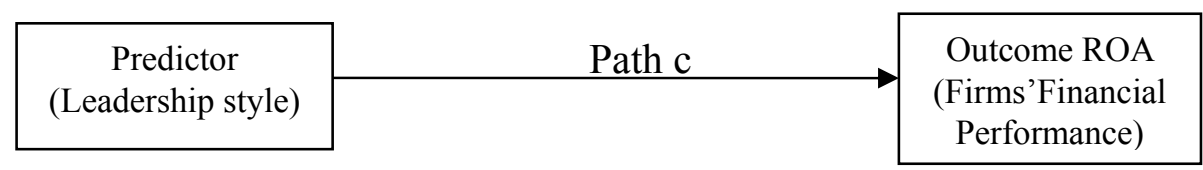

B.

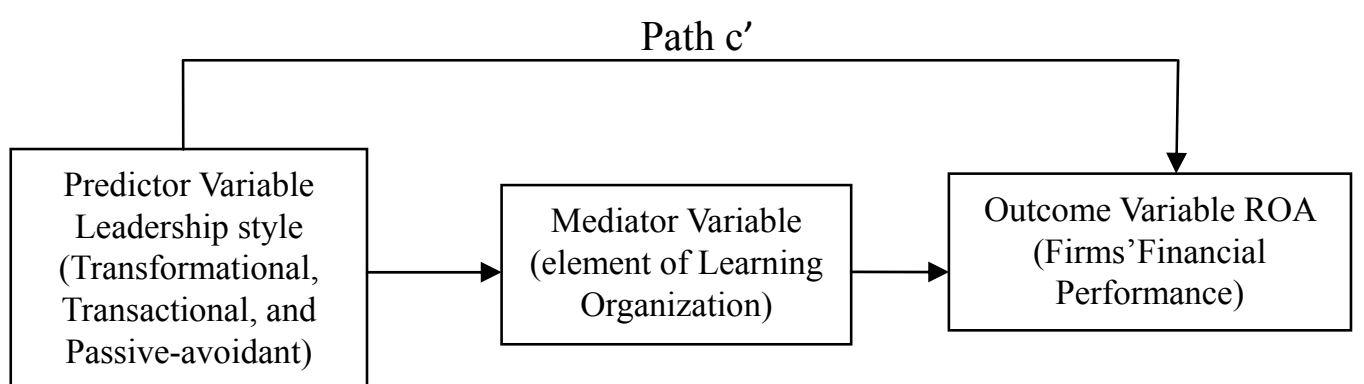

Figure 1. Conceptual frameworks of paths in mediation models

The Z score of mediation effect $=\mathrm{ab} / \mathrm{square}$ root of $b^{2} s a^{2}+a^{2} s b^{2}+s a^{2} s b^{2}$. Where $a$ and $b$ are unstandardized regression coefficients and $s a$ and $s b$ are their standard errors. The mediation effect will occur if the $\mathrm{Z}$ score is greater than 1.96 and the effect is significant at the .05 level.

Lastly, Kenny et al., (1998) proposed the formula of effect sample size to decide before run on the processes of mediation. The formula of effect sample size shows detail as follows: The effect sample size of mediation as: $N$ $\left(1-\mathrm{r}_{x m}{ }^{2}\right)$. Where $N$ is the sample size and $\mathrm{r}_{x m}$ is the correlation between the predictor and the mediator.

\section{Research Methodology}

The quantitative research techniques were manipulated for this study because it was suitable to verify theories, identify significant of variables and relate variables in hypotheses (Creswell, 2003). Multiple linear regression analysis and mediation effect methodologies were used in this case.

\subsection{Reliability and Validity}

The reliability of the 45 questionnaires of MLQ and the 43 questionnaires of DLOQ were tested by Cronbach'alpha method which are high scores at rate as .974 and .970 for reliability.

The effect sample size of mediation as: $N\left(1-\mathrm{r}_{x m}{ }^{2}\right)$. Where $N$ is the sample size and $\mathbf{r}_{x m}$ is the correlation between the predictor and the mediator. The correlation between the predictor (Leadership styles) and the mediator (Learning organization is 0.965 . Therefore, the effect sample size of mediation as: $400\left(1-(0.965)^{2}\right)=27.6$. The effect sample size of mediation in this study is at least 27.6 samples.

Validity refers to the reflection of scope for measuring objective (Babbie, 2007). The validity of the MLQ instrument was proved quite many times in the past because it has been widely used in several researches to explore the full range of leadership styles and outcomes (Bass \& Avolio, 1995; Bass, 1997; Avolio \& Bass, 2004). Moreover, Dumdum et al. (2002) revised the work of Lowe et al. (1996) by meta-analysis which the scales of 
MLQ are also quite similar. The MLQ not only has been used continually in several researches but it also still sustain in the high degrees of reliability and validity (Judge \& Piccolo, 2004). The validity of the DLOQ instrument, Watkins and Marsick (1997) developed the DLOQ instrument to test the relationship between learning organization and performance outcomes (Ellinger et al., 2003; Marsick \& Watkins, 2003; McHargue, 2000). Yang (2003) examined the method of confirmatory factor analysis (CFA) on the data for validity of DLOQ instrument. He found the score as .82 to .93 on the seven learning organization dimensions. Later, Yang et al. (2004) again tested the construct validity by confirmatory factor analysis CFA) which the score as .88 to .94 for the seven learning organization dimensions. Therefore, both Yang and Yang et al. inferred that the DLOQ instrument is advantaged for measuring the relationship between seven learning organization dimensions and performance outcomes.

\subsection{Research Questions and Research Hypotheses (Figure 2 Conceptual Framework)}

1) Do the Leadership styles (transformational, transactional and passive-avoidant) have an influence on ROA? If so, what does the element of the leadership styles influences?

Hypothesis 1a: At least one element of transformational leadership influence positively toward firms' financial Performance (ROA).

Hypothesis 1b: At least one element of transactional leadership influence positively toward firms' financial Performance (ROA).

Hypothesis 1c: At least one element of passive-avoidant influence positively toward firms' financial Performance (ROA).

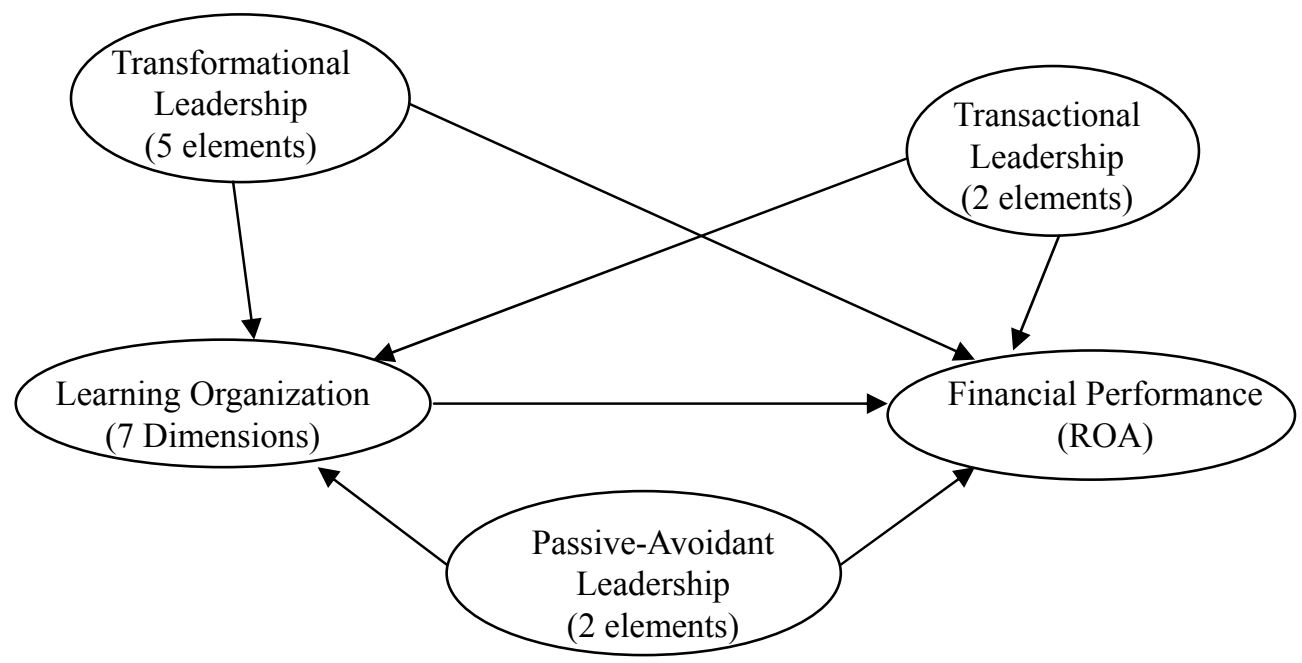

Figure 2. Conceptual framework

2) Do the leadership styles (transformational, transactional and passive-avoidant) have an influence on learning organization? If so, what does the element of the leadership influences?

Hypothesis 2a: At least one element of transformational leadership influence positively toward learning organization.

Hypothesis 2b: At least one element of transactional leadership influence positively toward learning organization.

Hypothesis 2c: At least one element of passive-avoidant influence positively toward learning organization.

3) Does the element of learning organization have an influence on ROA? If so, what does the element of the learning organization influences?

Hypothesis 3: At least one element of learning organization influence positively toward firms' financial Performance (ROA). 
4) Does the Learning Organization mediate on the relationship between Leadership styles (transformational, transactional and passive-avoidant) and ROA? If so, how, what does the element of Learning Organization mediate?

Hypothesis 4a: At least one element of the learning organization will mediate on the relationship between at least one element of transformational leadership style and Firms' Financial Performance (ROA).

Hypothesis 4b: At least one element of the learning organization will mediate on the relationship between at least one element of transactional leadership style and Firms' Financial Performance (ROA).

Hypothesis 4c: At least one element of the learning organization will mediate on the relationship between at least one element of passive-avoidant style and Firms' Financial Performance (ROA).

\section{Results}

\subsection{Descriptive Analysis}

Leadership style is the independent variable while ROA is the dependent variables. The learning organization is the mediator between the relationship of leadership styles and the ROA (Figure 4 Results on framework).

Hypothesis 1a: At least one element of transformational leadership that influences positively toward firms' financial Performance (ROA).

Table 1 presents the result of each independent variable (five elements of transformational) in regression analysis. The null hypothesis can be rejected because Individualized Consideration(IC) variable has influenced positively toward ROA at a 0.01 significance level.

Table 1. Transformational leadership and ROA

\begin{tabular}{lcccc}
\hline Model & B & Std. Error & Beta & Sig. \\
\hline & -8.193 & 2.718 & & 0.003 \\
IIA & -1.026 & 1.086 & -0.086 & 0.345 \\
IIB & -0.048 & 1.518 & -0.004 & 0.975 \\
IM & 0.961 & 1.125 & 0.077 & 0.393 \\
IS & 1.33 & 1.119 & 0.106 & 0.235 \\
IC & 3.306 & 1.252 & 0.305 & 0.009 \\
\hline
\end{tabular}

Note: a Dependent Variable: ROA, (IIA) Idealized Influence (Attributed), (IIB) Idealized Influence (Behavior), (IM) Inspirational Motivation, (IS) Intellectual Stimulation, and (IC) Individualized Consideration

Hypothesis 1b: At least one element of transactional leadership that influences positively toward firms' financial Performance (ROA).

Table 2 presents the result of each independent variable (two elements of transactional) in regression analysis. The null hypothesis can be rejected because (CR) Contingent Reward variable has influenced positively ROA at a 0.01 significance level.

Hypothesis 1c: At least one element of passive-avoidant that influences positively toward firms' financial Performance (ROA).

Table 2. Transactional leadership and ROA

\begin{tabular}{lcccc}
\hline Model & B & Std. Error & Beta & Sig. \\
\hline (Constant) & -7.234 & 2.36 & & 0.002 \\
CR & 3.097 & 0.762 & 0.271 & 0.000 \\
MBEA & 1.37 & 0.732 & 0.125 & 0.062 \\
\hline
\end{tabular}

Note: (CR) Contingent Reward, (MBEA) Management by Exception (Active)

Table 3 presents the result of each independent variable (two elements of passive-avoidant) in regression analysis. The null hypothesis can be rejected because Laissez-faire leadership (LF) variable has influenced positively 
toward ROA at a 0.01 significance level.

Hypothesis 2a: At least one element of transformational leadership influence positively toward learning organization.

Table 3. Passive-avoidant leadership and ROA

\begin{tabular}{lcccc}
\hline Model & B & Std. Error & Beta & Sig. \\
\hline (Constant) & -6.752 & 1.875 & & 0.000 \\
MBEP & 1.129 & 0.905 & 0.119 & 0.213 \\
LF & 3.06 & 0.865 & 0.336 & 0.000 \\
\hline
\end{tabular}

Note: a Dependent Variable: ROA, (MBEP) Management by Exception (Passive) and (LF) Laissez-faire

Table 4 presents the result of each independent variable (five elements of transformational) in regression analysis. The null hypothesis can be rejected because (IIA) Idealized Influence (Attributed), (IIB) Idealized Influence (Behavior), (IM) Inspirational Motivation, (IS) Intellectual Stimulation, and (IC) Individualized Consideration variables have influenced positively toward learning organization at a 0.01 significance level.

Hypothesis 2b: At least one element of transactional leadership influence positively toward learning organization.

Table 4. Transformational leadership and learning organization

\begin{tabular}{lcccc}
\hline Model & B & Std. Error & Beta & Sig. \\
\hline (Constant) & 0.654 & 0.07 & & 0.00 \\
IIA & 0.146 & 0.029 & 0.174 & 0.00 \\
IIB & 0.127 & 0.04 & 0.146 & 0.00 \\
IM & 0.08 & 0.03 & 0.091 & 0.01 \\
IS & 0.207 & 0.03 & 0.233 & 0.00 \\
IC & 0.29 & 0.033 & 0.374 & 0.00 \\
\hline
\end{tabular}

Note: a Dependent Variable: LO, (IIA) Idealized Influence (Attributed), (IIB) Idealized Influence (Behavior), (IM) Inspirational Motivation, (IS) Intellectual Stimulation, and (IC) Individualized Consideration

Table 5 presents the result of each independent variable (two elements of transactional) in regression analysis. The null hypothesis can be rejected because (CR) Contingent Reward and (MBEA) Management by Exception (Active) leadership variables have influenced positively toward learning organization at a 0.01 significance level.

Hypothesis 2c: At least one element of passive-avoidant leadership influence positively toward learning organization.

Table 5. Transactional leadership and learning organization

\begin{tabular}{lcccc}
\hline Model & B & Std. Error & Beta & Sig. \\
\hline (Constant) & 0.934 & 0.066 & & 0.00 \\
CR & 0.505 & 0.022 & 0.616 & 0.00 \\
MBEA & 0.303 & 0.021 & 0.384 & 0.00 \\
a Dependent Variable: LO & & & \\
\hline
\end{tabular}

Note: a Dependent Variable: LO, (CR) Contingent Reward, (MBEA) Management by Exception (Active)

Table 6 presents the result of each independent variable (two elements of passive-avoidant) in regression analysis. The null hypothesis can be rejected because (MBEP) Management by Exception (passive) and (LF) Laissez-faire leadership variables have influenced positively toward learning organization at a 0.01 significance level.

Hypothesis 3: At least one element of learning organization influence positively toward firms' financial Performance (ROA). 
Table 6. Passive-avoidant leadership and learning organization

\begin{tabular}{lcccc}
\hline Model & B & Std. Error & Beta & Sig. \\
\hline (Constant) & 1.579 & 0.053 & & 0.00 \\
MBEP & 0.353 & 0.026 & 0.525 & 0.00 \\
LF & 0.277 & 0.025 & 0.434 & 0.00 \\
\hline
\end{tabular}

Note: a Dependent Variable: LO, Management by Exception (Passive) and (LF) Laissez-faire

Table 7 presents the result of each independent variable (seven elements of learning) in regression analysis. The null hypothesis can be rejected because (B) Promote inquiry, (E) Empower people, and (G) Provide strategic variables have influenced positively toward ROA at 0.01 and 0.05 significance level.

Hypothesis 4a: At least one element of the learning organization will mediate on the relationship between at least one element of transformational leadership style and Financial Performance (ROA).

Table 7. Learning organization and ROA

\begin{tabular}{lcccc}
\hline Model & B & Std. Error & Beta & Sig. \\
\hline (Constant) & -10.701 & 3.107 & & 0.001 \\
A & -1.258 & 1.127 & -0.095 & 0.265 \\
B & 2.817 & 1.014 & 0.265 & 0.006 \\
C & 1.541 & 1.026 & 0.141 & 0.134 \\
D & -2.095 & 1.370 & -0.162 & 0.127 \\
E & 1.765 & 0.851 & 0.159 & 0.039 \\
F & -0.249 & 0.982 & -0.022 & 0.800 \\
G & 2.581 & 1.020 & 0.200 & 0.012 \\
\hline
\end{tabular}

Note: a Dependent Variable: ROA, (A) Create continuous learning opportunities, (B) Promote inquiry and dialogue, (C) Encourage collaboration and team learning, (D) Create systems to capture and share learning, (E) Empower people toward a collective vision, (F) Connect the organization to its environment, and (G) Provide strategic leadership for learning

Table 8 was accommodated from table 1, table 2, table 3, and table 7 . This table presents the result of each independent variable which are IC the element of transformational, CR the element of transactional, LF the element of passive-avoidant, and B, E, G the elements of learning organization have influenced positively toward ROA. All variables are used in the next step of equations model testing.

Figure 4 presents the process of paths in mediation effect testing by multiple regressions (Figure 3 Diagrams of the Paths in Mediation Testing).

Table 8. Results of transformational, transactional, passive-avoidant, and learning organization to ROA

\begin{tabular}{lcccc}
\hline Model & B & Std. Error & Beta & Sig. \\
\hline $\begin{array}{l}\text { Transformational } \\
\text { IC }\end{array}$ & 3.306 & 1.252 & 0.305 & 0.009 \\
$\begin{array}{l}\text { Transactional } \\
\text { CR }\end{array}$ & 3.097 & 0.762 & 0.271 & 0.000 \\
$\begin{array}{l}\text { Passive-avoidant } \\
\text { LF }\end{array}$ & 3.06 & 0.865 & 0.336 & 0.000 \\
Learning organization & & & & \\
B & 2.817 & 1.014 & 0.265 & 0.006 \\
E & 1.765 & 0.851 & 0.159 & 0.039 \\
G & 2.581 & 1.020 & 0.200 & 0.012 \\
\hline
\end{tabular}

Note: a Dependent Variable: ROA, (CR) Contingent Reward, (LF) Laissez-faire leadership, (B) Promote inquiry and dialogue, (E) Empower people toward a collective vision, $(\mathrm{G})$ Provide strategic leadership for learning. 


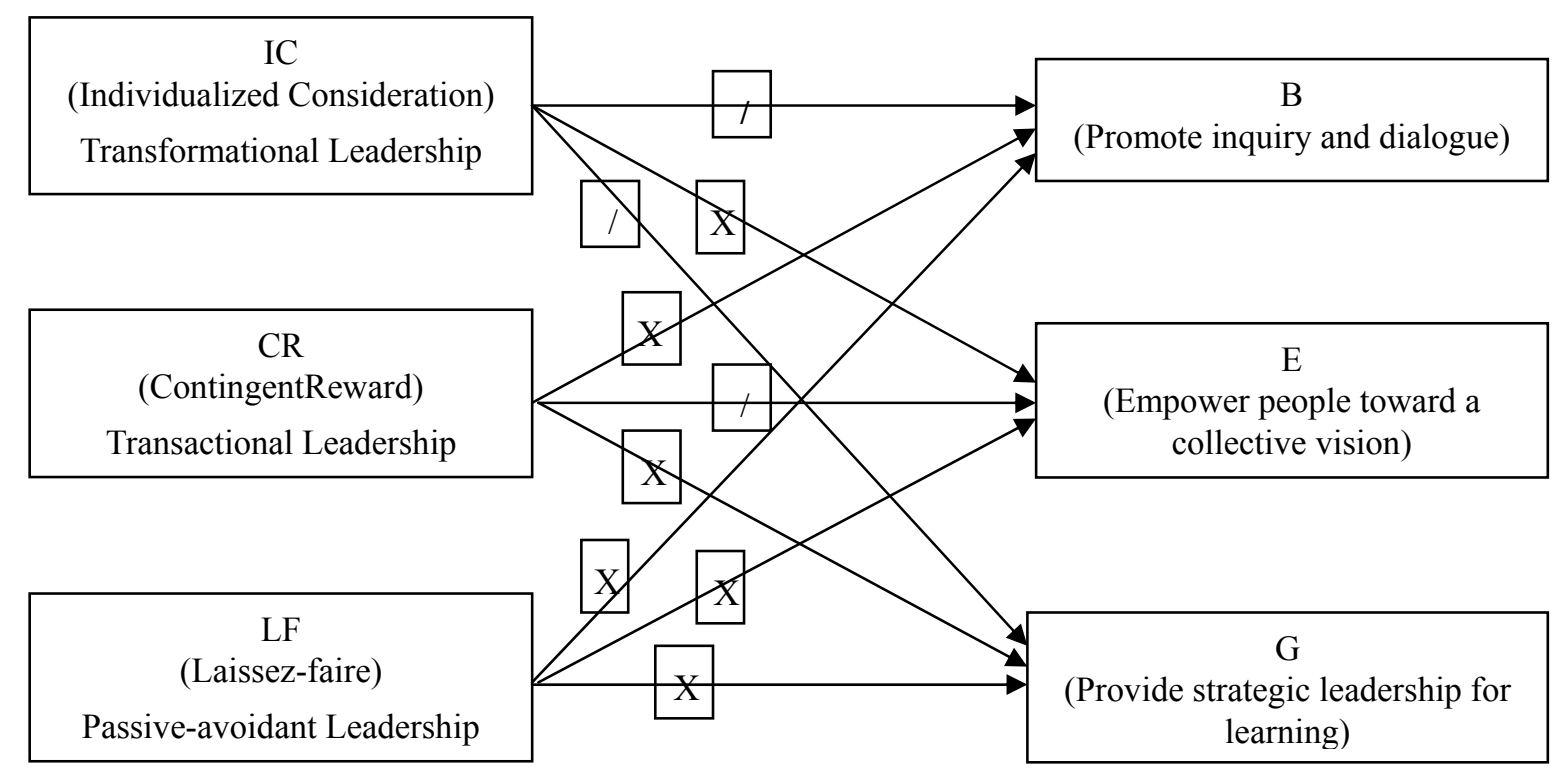

Figure 3. Diagrams of the paths in mediation testing (ROA) Note: $\quad=$ Mediation effect requirements; $\mathrm{X}=$ No mediation effect requirements

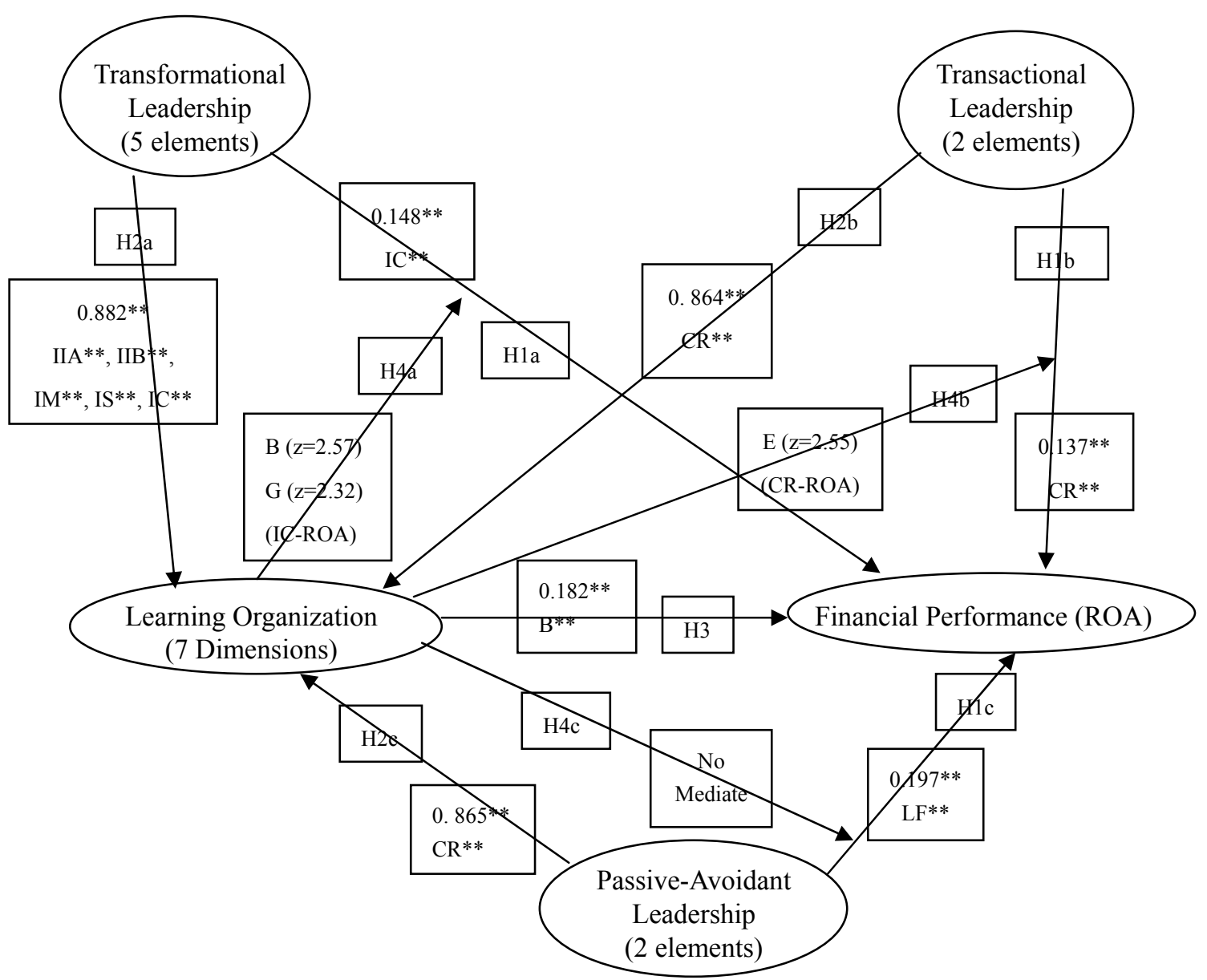

Figure 4. Results on framework 
Table 9 presents the result of mediation effect hypothesis. The step 1 Path c testing, IC (Transformational Leadership) predictor related to ROA outcome, met to mediation requirement, unstandardized regression coefficient $(B)$ is 4.041 , significant at 0.000 . Step 2 (Path a) testing, IC predictor (Transformational Leadership) related to $\mathrm{B}$ mediator (Learning Organization), met to mediation requirement, unstandardized regression coefficient $(B)$ is 0.825 , significant at 0.000 . Step 3(Path b) and (Path c') testing, the relation between B mediator and ROA by IC predictor controlling is met, unstandardized regression coefficient $(B)$ is 2.292 , significant at 0.010 . The result of unstandardized regression coefficient of Path $c^{\prime}$ is 2.110 , significant at 0.020 . Therefore, this model was partial mediation. $\mathrm{Z}$ score is 2.573 greater than 1.96 . The mediation effect has occurred. B mediator (Learning Organization) mediated on relationship between IC predictor (Transformational Leadership style) and ROA outcome.

Table 9. Mediation effects by multiple regressions using: B mediates on IC and ROA

\begin{tabular}{lccc}
\hline Testing steps in mediation model (B mediates on IC and ROA) & $B$ & $S E B$ & Sig. \\
\hline $\begin{array}{l}\text { Testing Step 1 (Path c) } \\
\text { Outcome: ROA }\end{array}$ & & & \\
Predictor: IC (Transformational Leadership) & 4.041 & 0.512 & 0.000 \\
Testing Step 2 (Path a) & & & \\
Outcome: B (Learning Organization) & 0.825 & 0.029 & 0.000 \\
Predictor: IC (Transformational Leadership) & & & \\
Testing Step 3 (Paths b and c') & & & \\
Outcome: ROA & 2.292 & 0.886 & 0.010 \\
Mediator: B, Learning Organization (Path b) & 2.110 & 0.903 & 0.020 \\
Predictor: IC, Transformational Leadership (path c')
\end{tabular}

Note: $\mathrm{IC}=$ Individualized Consideration, $\mathrm{B}=$ Promote inquiry and dialogue

Table 10 presents the result of mediation hypothesis. The step 1 Path $\mathrm{c}$ testing, IC predictor (Transformational Leadership) related to the ROA outcome, met to mediation requirement, unstandardized regression coefficient $(B)$ is 4.041, significant at 0.000 . Step 2 (Path a) testing, IC predictor (Transformational Leadership) related to G mediator (Learning Organization), met to mediation requirement, unstandardized regression coefficient $(B)$ is 0.454, significant at 0.000 . Step 3(Path b) and (Path c') testing, the relation between G mediator and ROA by IC predictor controlling is met, unstandardized regression coefficient $(B)$ is 1.715 , significant at 0.018 . The result of unstandardized regression coefficient of Path $c^{\prime}$ is 3.251 , significant at 0.000 . Therefore, this model was partial mediation. $\mathrm{Z}$ score is 2.322 greater than 1.96. The mediation effect has occurred. G mediator (Learning Organization) mediated on relationship between IC predictor (Transformational Leadership style) and ROA outcome.

Table 10. Mediation effects by multiple regressions using: G mediates on IC and ROA

\begin{tabular}{lccc}
\hline Testing steps in mediation model (G mediates on IC and ROA) & $B$ & SE B & Sig. \\
\hline $\begin{array}{l}\text { Testing Step 1 (Path c) } \\
\text { Outcome: ROA }\end{array}$ & & & \\
Predictor: IC (Transformational Leadership) & 4.041 & 0.512 & 0.000 \\
Testing Step 2 (Path a) & & & \\
Outcome: G (Learning Organization) & 0.454 & 0.035 & 0.000 \\
Predictor: IC (Transformational Leadership) & & & \\
Testing Step 3 (Paths b and c') & & & \\
Outcome: ROA & 1.715 & 0.725 & 0.018 \\
Mediator: G, Learning Organization (Path b) & 3.251 & 0.609 & 0.000 \\
Predictor: IC, Transformational Leadership (path c')
\end{tabular}

Note: $\mathrm{IC}=$ Individualized Consideration, $\mathrm{G}=$ Provide strategic leadership for learning 
Therefore, the null hypothesis can be rejected. Hypothesis 4a: There is an at least one element of the learning organization mediated on the relationship between at least one element of transformational leadership style and Firms' Financial Performance (ROA). B and G mediators (Learning Organization) mediated on the relationship between IC predictor (Transformational Leadership style) and ROA outcome.

Hypothesis $4 \mathrm{~b}$ : At least one element of the learning organization will mediate on the relationship between at least one element of transactional leadership style and Firms' Financial Performance (ROA).

Table 11 presents the result of mediation hypothesis. The step 1 Path $\mathrm{c}$ testing, CR predictor (transactional leadership) related to the ROA outcome, met to mediation requirement, unstandardized regression coefficient $(B)$ is 4.101, significant at 0.000. Step 2 (Path a) testing, CR predictor (transactional leadership) related to E mediator (learning organization), met to mediation requirement, unstandardized regression coefficient $(B)$ is 0.691 , significant at 0.000 . Step 3(Path b) and (Path c') testing, the relation between E mediator and ROA by CR predictor controlling is met, unstandardized regression coefficient $(B)$ is 1.843 , significant at 0.010 . The result of unstandardized regression coefficient of Path ' ${ }^{\prime}$ is 2.806 , significant at 0.000 . Therefore, this model is partial mediation. $\mathrm{Z}$ score is 2.553 greater than 1.96 . The mediation effect has occurred. E mediator (learning organization) mediated on the relationship between CR predictor (transactional leadership style) and ROA outcome.

Therefore, the null hypothesis can be rejected. Hypothesis $4 \mathrm{~b}$ : There is an at least one element of the learning organization will mediate on the relationship between at least one element of transactional leadership style and Firms' Financial Performance (ROA). E mediator (learning organization) mediated on the relationship between CR predictor (transactional leadership style) and ROA outcome.

Table 11. Mediation effects by multiple regressions using: E mediates on CR and ROA

\begin{tabular}{lccc}
\hline Testing steps in mediation model (E mediates on CR and ROA) & $B$ & $S E B$ & Sig. \\
\hline $\begin{array}{l}\text { Testing Step 1 (Path c) } \\
\text { Outcome: ROA }\end{array}$ & & & \\
Predictor: CR (Transactional Leadership) & 4.101 & 0.543 & 0.000 \\
Testing Step 2 (Path a) & & & \\
Outcome: E (Learning Organization) & 0.691 & 0.038 & 0.000 \\
Predictor: CR (Transactional Leadership) & & & \\
Testing Step 3 (Paths b and c') & & & \\
Outcome: ROA & 1.843 & 0.716 & 0.010 \\
Mediator: E, Learning Organization (Path b) & 2.806 & 0.738 & 0.000 \\
Predictor: CR, Transactional Leadership (path c')
\end{tabular}

Note: $\mathrm{CR}=$ Contingent Reward, $\mathrm{E}=$ Empower people toward a collective vision

Hypothesis 4c: At least one element of the learning organization will mediate on the relationship between at least one element of passive-avoidant style and Firms' Financial Performance (ROA).

No element of learning organization mediated on the relationship between passive-avoidant leadership style and ROA because the paths are not met requirement of mediation effect. Therefore, the null hypothesis can be fail to rejected (H04c).

\section{Conclusions}

\subsection{The Relationship of Leadership Styles and ROA}

(IC) Individualized Consideration (transformational leadership), (CR) Contingent Reward (transactional leadership), and (LF) Laissez-faire (passive-avoidant leadership) have influenced positively toward ROA.

According to Bass's (1990) theory, he stated that transformational and transactional leadership styles are the most effective on productivity and performances while laissez-faire is lowest ranking. The results of this study related to his concepts because the major of transformational, transactional, and passive-avoidant leadership styles related to ROA performances, although some elements didn't relate. The relationship between transformational leadership styles and performance from these results are congruent to results of previous researches (Bass, 1997; Dubinsky et al., 1995; Duckett \& Macfarlane, 2003; Felfe \& Schyns, 2004; Chen et al., 
2005; Spinelli, 2006, Hayashi \& Ewert, 2006). While results of relation between transactional leadership styles and performance are also congruent to results of previous researches (Dubinsky et al., 1995; Humphreys, 2002a; Spinelli, 2006). However, results of relationship between Laissez-faire, passive-avoidant leadership styles and performance are also congruent to results of previous researches. Beer \& Eisenstat (2002); Chen et al. (2005); Spinelli (2006) stated that the effective of passive-avoidant leadership, specific between laissez-faire and performance are weak or negative results.

\subsection{The Relationship of Leadership Styles and Learning Organization}

All nine elements of leadership styles related significantly toward learning organization. This relationship is supported by many notions of researchers such as Woolner (1995) stated that leaders have to plan and create the development for learning organization. Senge (1990b) proposed that the leaders must respond to establishing for learning organization. While Bennis and Nanus (1985) supported in the same way that leaders are going to be the expert at learning in their organization. Marquardt (1996) also proposed the concept of "keys to success" for leaders to perform in learning organization. Therefore, leaders have to take the role of leadership in learning organization (Senge, 1990b; Denton \& Wisdom, 1991). Leaders not only must create in learning organization but also focus on surrounding which effect to organization (Rolls, 1995). While, Garvin (2000) suggested three primary learning for leaders which are consist of knowledge creation, fostering of engagement, and encouraging of discussion within members. In this study, researcher integrated between the nine elements of leadership styles by theory of Bass and Avolio's (2004) and dimension of learning organization by theory of Watkins and Marsick's (2003).

\subsection{The Relationship of the Elements of Learning Organization and ROA}

The (B) Promote inquiry, (E) Empower people, and (G) Provide strategic (element of learning organization) have influenced positively toward ROA.

$\mathrm{B}$, E, and $\mathrm{G}$ elements of learning organization were able to relate to ROA. Provide strategic $(\mathrm{G})$ related significantly to ROA. The previous researches which results related to learning organization and organizational performance were following: Seden (1998); McHargue (2000); Hernandez (2001); Ellinger et al. (2002); Lien et al. (2002); Zhang et al. (2003); Power \& Waddell (2004); Kumar \& Idris (2006); and Chajnacki (2007). But only some previous research studied on the relation between learning organization and financial performance such as Seden (1998); Ellinger et al. (2002); and Chajnacki (2007).

The results of this study on R-square of regression model for seven dimension of learning organization and financial Performance at ROA was 18.2 percent of variation which could be explained. While previous researches of Ellinger et al. (2002), R-square of regression model for learning dimension and financial Performance were 10.8 percent. Moreover, Chajnacki (2007), R-square of regression model for learning dimension and financial Performance were only 1.1 percent of variation which could be explained. The results were still supported the relation between learning organization and firm's financial performances.

5.4 Some Elements of the Learning Organization Mediated on the Relationship between Some Elements of Transformational Leadership Style and ROA

Promote inquiry (B) and Provide strategic (G) mediators (learning organization) mediated partially on the relationship between (IC) Individualized Consideration (transformational leadership) and ROA. Moreover, Empower people (E) mediator (learning organization) mediated partially on the relationship between (CR) Contingent Reward (transactional leadership) and ROA.

$\mathrm{B}$ and $\mathrm{G}$ mediators (learning organization) were able to mediate on IC (transformational leadership) and ROA, and $\mathrm{E}$ mediator (learning organization) was able to mediate on CR (transactional leadership) and ROA because all mediators (B, G, and E) met the requirement of mediation effect methodology. This section of study was similar the previous research study of Frazier, Tix, and Barron (2004) which referred to original theory of Baron and Kenny (1986).

However, no element of learning organization mediate on the relationship between passive-avoidant leadership style and ROA because the paths are not met requirement of mediation effect in multiple regressions testing.

\section{Discussion}

The relationship of leadership styles (transformational, transactional and passive-avoidant) and ROA

The overall results of this section, research still confirm the theory on Bass's (1990) and Bass and Avolio (1990, 1993, 1994, 1995, 2001, \& 2004) which the leadership styles can impact to organizational performance. Although, results of transformational and transactional leadership styles supported theory but result of (LF) 
laissez-faire, element of passive-avoidant leadership styles are become highest than others in this study. The result of laissez-faire (LF) which related to ROA are different from others researches studies.

The relationship of leadership styles (transformational, transactional and passive-avoidant) and learning organization

All nine elements of leadership styles related significantly with high score toward learning organization. Researcher has comments on this results that all leadership styles have relationship to learning organization because many activities of leaders which are implement, it effect to processes of learning organization supporting (Senge, 1990b).

However, leadership styles must encourage to processes of learning organization and in opposite, learning organization has to support knowledge, knowhow, and technique to leaders to achieve the organizational goals. Although, there are the best leadership styles work in organization but learning organization do not support them or conversely, learning organization is strong culture but it is without leaders to handle in organization. Consequently, the confliction can lead to the organizational cessation. Therefore, leadership styles and learning organization are very important and direct effect to organizational performances.

The relationship of the elements of learning organization and $R O A$

The results of this section encouraged the theory of learning organization by Watkins and Marsick (1993, 1997, \& 2003). Researcher has comments on this point that although R-square of regression model for learning dimension and financial Performance in this results and previous researches are around 10 percent of variation which can be explain. However, it is able to imply that (1) to know dimensions of learning organization which impact or not impact to financial performance. (2) To focus on the dimensions those are impact to financial performances. (3) To improve on the dimensions those are not impact to financial performances until it become to significance in processes of learning organization and financial performances.

Some elements of the learning organization mediated on the relationship between some elements of transformational leadership style and ROA

The results of this section encouraged the theory of leadership styles by Bass and Avolio (1990, 1993, 1994, 1995, 2001, \& 2004); learning organization by Watkins and Marsick (1993, 1997, \& 2003); and mediation effect of Baron and Kenny (1986). However, Researcher has comments on this results that (1) the power of IC (Individualized Consideration) is the most effective to ROA because the style of Individualized Consideration (IC), leaders who have behaviors that advising, encouraging, teaching, coaching, and paying attention to the individual talents and needs of follower rather than as a member of the group. These behaviors may lead members to the conflict between leaders and team members in organization. Conversely, process of learning organization encourage the members to share the knowledge, knowhow, and technique to others rather than individual. Therefore, leaders should focus on others styles of leadership in order to improve the effective on organization. Furthermore, the power of Contingent Reward (CR) leadership the style is still active because follows are going to expect the exchange for more performance so, motivation always used in processes of management in organization. (2) The mediators B (Promote inquiry) and G (Provide strategic) of learning organization mediated on IC (Individualized Consideration) of the transformational leadership style and ROA. From this results, researcher commented that when leaders IC (Individualized Consideration) style emphasize on talent people, processes of learning are occurred because they dialogue and share ideas or skills to other people. Therefore, B (Promote inquiry) and G (Provide strategic) of learning organization and IC (Individualized Consideration) of the transformational leadership style are integrated toward ROA. (3) The mediators E (Empower people) of learning organization mediated on CR (Contingent Reward) of the transactional leadership style and ROA. From these results, researcher commented that when leaders CR (Contingent Reward) style motivate the follows to generate performance over expectation, the follows are going to create ideas for their performance because they are empowered and take responsibility from leaders. The processes of learning organization are occurred. Lastly, E (Empower people) of learning organization and CR (Contingent Reward) of the transactional leadership style are integrated toward and ROA.

\section{References}

Antonakis, J., Avolio, B. J., \& Sivasubramaniam, N. (2003). Context and leadership: An examination of the nine factor full-range leadership theory using the multifactor leadership questionnaire. The Leadership Quarterly, 14(3), 261-295. http://dx.doi.org/10.1016/S1048-9843(03)00030-4

Avolio, B J., \& Bass, B. M. (1997). The Full Range Leadership Development Manual ForThe Multifactor 
Leadership Questionnaire. Redwood City, CA: Mindgarden.

Avolio, B. J., \& Bass, B. M. (1991). The full range leadership development program: Basic and advanced manuals. Binghamton, NY: Bass, Avolio \& Associates.

Avolio, B. J., \& Bass, B. M. (1994). Improving organizational effectiveness through Transformational leadership. CA: Sage.

Avolio, B. J., \& Bass, B. M. (2003). The Full Range Leadership Multifactor Leadership Questionnaire. Palo Alto, CA: Mindgarden.

Avolio, B. J., \& Bass, B. M. (2004). Multifactor Leadership Questionnaire: Third edition manual \& sampler set. Menlo Park, CA: Mind Garden, Inc.

Avolio, B. J., Bass, B. M., \& Jung, D. I. (1999). Re-examining the components of transformational and transactional leadership using the Multifactor Leadership Questionnaire. Journal of Occupational and Organizational Psychology, 72, 441-462. http://dx.doi.org/10.1348/096317999166789

Avolio, B. J., Waldman, D. A., \& Yammario, F. J. (1991). Leading in the 1990s: the four Is of transformational leadership. Journal of European Industrial Training, 15(4), 9-16. http://dx.doi.org/10.1108/03090599110143366

Babbie, E. R. (2007). The practice of social research (11th ed.). Belmont, CA: Thomson Wadsworth.

Barbuto Jr., \& J. E. (2005). Motivation and transactional, charismatic, and transformational leadership: A test of antecedents. Journal of Leadership and Organizational Studies, 11(4), 26-41. http://dx.doi.org/10.1177/107179190501100403

Barling, J., Slater, F., \& Kelloway, E. (2000). Transformational Leadership and emotional intelligence: an exploratory study. Leadership and Organizational Development Journal, 21, 157-161. http://dx.doi.org/10.1108/01437730010325040

Baron, R. M., \& Kenny, D. A. (1986). The moderator-mediator variable distinction in social psychological research: Conceptual, strategic, and statistical consideration. Journal of Personality and Social Psychology, 51, 1173-1182. http://dx.doi.org/10.1037/0022-3514.51.6.1173

Bass, B. M. (1985). Leadership and Performance: Beyond Expectations. New York: The Free Press.

Bass, B. M. (1996a). Is There Universality in the Full Range Model of Leadership? International Journal of Public Administration 19(6), 731-61. http://dx.doi.org/10.1080/01900699608525119

Bass, B. M. (1997). Does the transactional-transformational leadership paradigm transcend organizational boundaries?. American Psychologist, 52, 130-139. http://dx.doi.org/10.1037/0003-066X.52.2.130

Bass, B. M. (1998). Transformational leadership industrial, military, and educational impact. Mahwas. NJ: Lawrence Erlbaum Associates, Publishers.

Bass, B. M., \& Avolio, B. J. (1993). Transformational leadership: a response to critiques. In Chemers, M. M., \& Ayman, R. (Eds), Leadership Theory and Research: Perspectives and Directions (pp. 49-80). Orlando, FL: Academic Press.

Bass, B. M., \& Avolio, B. J. (1994). Improving leadership effectiveness through transformational leadership. New York: Sage.

Bass, B. M., \& Avolio, B. J. (1995). Multifactor Leadership Questionnaire. Menlo Park, CA: Mind Garden.

Bass, B. M., \& Avolio, B. J. (1996). Multifactor Leadership Questionnaire. Palo Alto, CA: Mind Garden.

Bass, B. M., \& Avolio, B. J. (1997). Full range leadership development: manual for the Multifactor Leadership Questionnaire. Palo Alto, CA: Mindgarden.

Bass, B. M., \& Avolio, B. J. (2004). Manual for the multifactor leadership questionnaire (MLQ - Form 5X). Redwood City, CA: Mindgarden.

Bass, B. M., \& Avolio, B. J. (2004). Multifactor Leadership Questionnaire: Manual and Sampler Set (3rd ed.). Redwood City, CA: Mind Garden.

Bass, B. M., \& Avolio, B. J. (2006). Multifactor Leadership Questionnaire: Abridged Self Rating Report. Retrieved from http://www.mlq.com.au/docs/sample_mlqself_report.pdf

Bass, B. M., Avolio, B. J., \& Jung, D. I. (1999, December). Re-examining the components of transformational 
and transactional leadership using the Multifactor Leadership Questionnaire. Journal of Occupational and Organizational Psychology, 72, 441-462. http://dx.doi.org/10.1348/096317999166789

Bass, B. M., Avolio, B. J., Jung, D. I., \& Berson, Y. (2003). Predicting unit performance by assessing transformational and transactional leadership. Journal of Applied Psychology, 88(2), 207-218. http://dx.doi.org/10.1037/0021-9010.88.2.207

Bass, B., Avolio, B., \& Jung, D. I. (1995). MLQ Multifactor Leadership Questionnaire (Technical Report). Redwood City, CA: Center for Leadership Studies, Binghamton University, Distributed by Mind Garden.

Burns, J. M. (1978). Leadership. New York: Harper \& Row.

Chajnacki, G. M. (2007). Characteristics of learning organizations and multi-dimensional organizational performance indicators: A survey of large, publicly-owned companies. Doctoral dissertation, Graduate School College of Education, Pennsylvania State University.

Creswell, J. (2003). Research Design. Thousand Oaks, CA: Sage Publications.

Davis, D. (2005). The learning organization and dimensions as key factors in firm performance. Doctoral dissertation, University of Wisconsin-Milwaukee.

Den Hartog, D. N., Van Mijen, J. J., \& Koopman, P. L. (1997, March). Transactional versus transformational leadership: An analysis of the MLQ. Journal of Occupational and Organizational Psychology, 70, 19-35. http://dx.doi.org/10.1111/j.2044-8325.1997.tb00628.x

Densten, I. L., Santos, J. C., Sarros, J. C., Tanewski, G. A., \& Winters, R. P. (2002). Work Alienation and organizational leadership. British Journal of Management, 13(4), 285. http://dx.doi.org/10.1111/1467-8551.00247

Dibella, A. J., \& Nevis, E. C. (1998). How organizations learn: an integrated strategy for building learning capability. San Francisco: Jossey-Bass.

Dixon, N. (1997). The hallways of learning. Organization Dynamics, 23(3), 133-143.

Dumdum, U. R., Lowe, K.B., \& Avolio, B. J. (2002). A meta-analysis of effectiveness and satisfaction: An update and extension. In B. J. Avolio \& F. J. Yammarino (Eds.), Transformational and charismatic leadership: the road ahead (pp. 35-66). Amsterdam: JAI.

Ellinger, A. D., Ellinger, A. E., Yang, B., \& Howton, S. W. (2003, May). Making the business case for the learning organization concept. Advances in Developing Human resources, 5(2), 163-172. http://dx.doi.org/10.1177/1523422303005002004

Garvin, D. A. (1993). Building learning organization. Harvard Business Review, 71(4), 78-91.

Garvin, D. A. (2000). Learning in action: a guide to putting the learning organization to work. Boston: Harvard Business School Press.

Goodwin, V. L., Wofford, J. C., \& Whittington, J. L. (2001, November). A theoretical and empirical extension to the transformational leadership construct. Journal of Organizational Behavior, 22(7), 759-774. http://dx.doi.org/10.1002/job.111

Harland, L., Harrison, W., Jones, J. R., \& Reiter-Palmon, R. (2005). Leadership behaviors and subordinate resilience. Journal of Leadership and Organizational Studies, 11(2), 2-14. http://dx.doi.org/10.1177/107179190501100202

Hitt, M. A., Robert, E. H., \& Hicheon, K. (1997). International Diversification: Effects on Innovation and Firm Performance in Product Diversified Firms. Academy of Management Journal, 40(4), 767-798. http://dx.doi.org/10.2307/256948

Howell, J. M., \& Avolio, B. J. (1993). Transformational leadership, transactional leadership. Locus of control and support for innovation: Key predictors of consolidated business-unit performance. Journal of Applied Psychology, 78, 891-902. http://dx.doi.org/10.1037/0021-9010.78.6.891

Judge, T. A., \& Piccolo, R. F. (2004). Transformational and transactional leadership: A meta-analysis test of their $\begin{array}{lllll}\text { relative validity. Journal of Applied Psychology, 89(5), } & \text { 755-768. }\end{array}$ http://dx.doi.org/10.1037/0021-9010.89.5.755

Kenny, D. A., Kashy, D. A., \& Bolger, N. (1998). Data analysis in social psychology. In D. T. Gilbert, S. T. Fiske, \& G. Lindzey (Eds.), The handbook of social psychology (4th ed., pp. 233-265). New York: Oxford University Press. 
King, A. W., \& Zeithaml, C. P. (2001). Competencies and Firm Performance: Examining the causal Ambiguity $\begin{array}{lllll}\text { Paradox. Strategic } & \text { Management } & \text { Journal, } & \text { 22, }\end{array}$ http://dx.doi.org/10.1002/1097-0266(200101)22:1\%3C75::AID-SMJ145\%3E3.0.CO;2-I

Lowe, K. B., Kroeck, K. G., \& Sivasubramaniam. (1996). Effectiveness correlates of transformational and transactional leadership: A meta-analysis of the MLQ literature. The Leadership Quarterly, 7(3), 385-425. http://dx.doi.org/10.1016/S1048-9843(96)90027-2

Marquardt, M. (2002). Building the learning organization: mastering the five elements for corporate learning. Palo Alto, CA: Davies-Black.

Marquardt, M., \& Alexander, J. (1999). How action learning builds the learning organization: a conceptual analysis. In K. P. Kuchinke (Ed.), Academy for Human Resource Development Conference Proceedings. Arlington, VA: AHRD Press.

Marsick, V. J., \& Watkins, K. E. (2003, May). Demonstrating the value of an organization's learning culture: the dimensions of the learning organization questionnaire. Advances in Developing Human Resources, 5(2), 132-151. http://dx.doi.org/10.1177/1523422303005002002

Matsuno, K., John, T. M., \& Özsomer, A. (2002). The effect of Entrepreneurial Proclivity and Market Orientation on Business Performance. Journal of Marketing, 66(3), 18-32. http://dx.doi.org/10.1509/jmkg.66.3.18.18507

McHargue, S. K. (2000, Dec). Dimensions of the learning organization as determinants of organizational performance in nonprofit organizations. Dissertation Abstracts International, 61(6), 2147.

Morgan, R. E., \& Strong, C. A. (2003). Business Performance and Dimensions of Strategic Orientation. Journal of Business Research, 56, 163-176. http://dx.doi.org/10.1016/S0148-2963(01)00218-1

Pedler, M., Burgoyne, J., \& Boydell, T. (1991). The learning company: a strategy for sustainable development. London: McGraw-Hill.

Redding, J. C., \& Catalanello, R. F. (1994). Strategic readiness: the making of the learning organization. San Francisco: Jossy-Bass.

Robinson, D., \& Robinson, J. (1995). Performance consulting: moving beyond training. San Francisco: Berrett-Koehler.

Rosenzweig, E. D., Aleda, V. R., \& Dean, J. W., Jr. (2003). The Influence of an Integration Strategy on Competitive Capabilities and Business Performance: An Exploratory Study of Consumer Products $\begin{array}{lllll}\text { Manufacturers. Journal of } & \text { Operations } & \text { Management, } & \text { 21, }\end{array}$ http://dx.doi.org/10.1016/S0272-6963(03)00037-8

Rowden, R. W. (2001). Learning organization and strategic change. SAM Advanced Management Journal, 66(3), 11-18.

Rowold, J., \& Heinitz, K. (2007). Transformational and charismatic leadership: Assessing the convergent, divergent and criterion validity of the MLQ and the CKS. The Leadership Quarterly, 18(2), 121-133. http://dx.doi.org/10.1016/j.leaqua.2007.01.003

Sarver, M. (2008). Leadership styles of Texas police chiefs and the correlates of the most effective leaders. Dissertation Abstracts International, 69(4).

Senge, P. (1990). The fifth discipline: the art and practice of the learning organization. New York: Doubleday.

Sergiouvanni, T. J. (1990). Adding value to leadership gets extraordinary results. Educational Leadership, 47(8), 23-27.

Waldman, D. A., Bass, B. M., \& Einstein, W. E. (1987). Leadership and the outcomes of the performance appraisal process. Journal of Occupational Psychology, 60, 177-186. http://dx.doi.org/10.1111/j.2044-8325.1987.tb00251.x

Watkins, K. E., \& Marsick, V. J. (1993). Sculpting the learning organization: lessons in the art and science of systemic change. San Francisco: Jossy-Bass.

Watkins, K. E., \& Marsick, V. J. (1996). In action: Creating the learning organization. Alexandria, VA: American Society for Training and Development.

Watkins, K. E., \& Marsick, V. J. (1997). Dimensions of the learning organization. Warwick, RI: Partners for the Learning Organization. 
Watkins, K. E., \& Marsick, V. J. (2003). Demonstrating the value of an organization's learning culture: the dimensions of the learning organization questionnaire. In K.E. Watkins (Ed.), Advances in Developing Human Resources, 5(1), 132-151.

Yamin, S., Gunasekaran, A., \& Mavondo, F. T. (1999). Relationship Between Generic Strategies, Competitive Advantage and Organizational Performance: An Empirical Analysis. Technovation, 19, 507-518. http://dx.doi.org/10.1016/S0166-4972(99)00024-3

Yammeesri, J., \& Sudhir C. L. (2004). Is Family Ownership a Pain or Gain to Firm Performance?. Journal of American Academy of Business, 4(1), 263-270.

Yang, B. (2003). Identifying valid and reliable measures for dimensions of a learning culture. Advances in Developing Human Resources, 5(2), 152-162. http://dx.doi.org/10.1177/1523422303005002003

Yang, B., Watkins, K., \& Marsick, V. J. (2004). The construct of the learning organization: Dimensions, measurement, and validation. Human Resource Development Quarterly, 15(1), 31-15. http://dx.doi.org/10.1002/hrdq.1086 